\title{
Korelasi Kadar Ion Kalsium Serum dengan Dimensi, Fungsi Sistol dan Diastol Ventrikel Kiri pada Thalassemia Mayor dengan Hemosiderosis
}

\author{
Ira Furnia, Dwi Prasetyo, Lelani Reniarti \\ Departemen Ilmu Kesehatan Anak Fakultas Kedokteran Universitas Padjadjaran/Rumah Sakit Dr. Hasan Sadikin, Bandung
}

Latar belakang. Kalsium berperan penting dalam kontraksi miokardium. Besi bebas/non-transferrin bound iron (NTBI) pada thalassemia mayor (TM) dengan kelebihan besi (hemosiderosis) masuk ke dalam sel jantung menggunakan L-typ e calcium channel (LTCC) sehingga mengganggu transportasi kalsium.

Tujuan. Menganalisis korelasi kadar ion kalsium serum dengan dimensi, fungsi sistol, dan diastol ventrikel kiri pada TM yang sudah mengalami hemosiderosis.

Metode. Penelitian potong lintang dilaksanakan dari Desember 2014-Januari 2015 melibatkan 67 kasus TM usia 7-14 tahun yang disertai hemosiderosis. Pemeriksaan kadar ion kalsium serum menggunakan metode ion selective electrode (ISE) dan pemeriksaan dimensi serta fungsi jantung menggunakan ekokardiografi 2 dimensi, $M$-mode, dan Doppler oleh dokter spesialis kardiologi anak. Analisis korelasi dengan uji Spearman dan Pearson.

Hasil. Uji korelasi Spearman menunjukkan korelasi negatif yang signifikan antara kadar ion kalsium serum dan left ventricular posterior wall thickness/LVPWd ( $\mathrm{r}=-0,25 ; \mathrm{p}=0,04)$. Uji korelasi Pearson menunjukkan korelasi negatif yang signifikan antara kadar ion kalsium serum dan ejection fraction/EF $(r=-0,294 ; \mathrm{p}=0,016)$ serta fractional shortening/ $\mathrm{FS}(\mathrm{r}=-0,252 ; \mathrm{p}=0,039)$, tetapi tidak dengan fungsi diastol ( $\mathrm{p}>0,05)$.

Kesimpulan. Semakin rendah kadar ion kalsium serum maka semakin tinggi nilai LVWP, EF, dan FS. Kadar ion kalsium serum tidak berkorelasi dengan fungsi diastol. Sari Pediatri 2015;17(3):195-9.

Kata kunci: fungsi sistol dan diastol, kadar ion kalsium serum, thalassemia mayor, hemosiderosis

\section{The Correlation of Serum Calcium Ion Level with Dimension, Systolic, and Diastolic Function of Left Ventricle in Hemosiderosis Thalassemia Major Children}

\author{
Ira Furnia, Dwi Prasetyo, Lelani Reniarti
}

Background. Calcium plays an important role in myocardial contractility. Free iron/non-transferrin bound iron (NTBI) in Thalassemia major (TM) patient with iron overload (hemosiderosis) enters the cardiomyocytes through the voltage dependent L-type calcium channels (LTCC) and inhibit calcium transportation. Correlation study of serum ion calcium level with cardiac function has never been performed.

Objectives. To determine the correlation of serum calcium ion level with chamber dimension, systolic, and dyastolic function in hemosiderosis TM children.

Method. We performed a cross-sectional analytic study to 67 children with TM during the period of December 2014-January 2015. Serum calcium ion level was measured with ion selective electrode method (ISE), dimension and cardiac dysfunction was measured with 2-dimension, M-mode, and Doppler echocardiography by a pediatric cardiologist. Pearson and Spearman correlation tests were used for analysis.

Results. Spearman correlation test showed a negative correlation between serum calcium ion level and left ventricular posterior wall thickness/LVPWd significantly $\left(r_{s}=-0.25 ; \mathrm{p}=0.04\right)$. Pearson correlation test showed a negative correlation between serum calcium ion and ejection fraction/EF $(r=-0.294 ; \mathrm{p}=0.016)$ and fractional shortening/FS $(\mathrm{r}=-0.252 ; \mathrm{p}=0.039)$ significantly but there was no correlation with diastolic function $(\mathrm{p}>0,05)$.

Conclusion. Decreasing serum calcium ion level was followed by increasing FS, EF, and LVWP.There is no correlation with diastolic function. Sari Pediatri 2015;17(3):195-9.

Keywords: cardiac dysfunction, dimension, hemosiderosis, hypocalcemia, left ventricle, thalassemia major

Alamat korespondensi: DR. Dr. Lelani Reniarti, SpA(K), M.Kes. Departemen Ilmu Kesehatan Anak Fakultas Kedokteran Universitas Padjadjaran/Rumah Sakit Dr. Hasan Sadikin Bandung. Jl. Pasteur No. 38 Bandung 40163. Tel. +62-22-3035957. E-mail: 1elanir@yahoo.com 
$T$

halassemia merupakan penyakit kelainan darah yang diturunkan akibat kelainan produksi rantai globin. ${ }^{1}$ Pemberian transfusi darah merah rutin sebagai terapi pada Thalassemia mayor (TM) terbukti memperpanjang harapan hidup pasien, tetapi membawa komplikasi lain akibat asupan besi yang berlebih., ${ }^{2,3}$ Kelebihan besi menyebabkan munculnya besi yang tidak terikat transferin atau disebut non-transferrin bound iron (NTBI). Non-transferrin bound iron bersifat toksik pada berbagai organ termasuk jantung karena dapat memicu pembentukan radikal bebas. ${ }^{4,5}$ Masuknya NTBI ke dalam sel tidak melalui umpan balik negatif, tetapi menggunakan L-type calcium channels (LTCC) yang merupakan saluran utama masuknya kalsium dan berkompetisi dengan $\mathrm{Ca}^{2+}$ karena keduanya memiliki ukuran dan muatan listrik yang sama. ${ }^{6,7}$ Kondisi hipokalsemia memungkinkan besi lebih banyak melewati LTCC dan meningkatkan deposit besi dalam sel miokardium yang akan menimbulkan stres oksidatif sehingga mengganggu kontraktilitas jantung. ${ }^{7,8}$ Peningkatan besi melalui LTCC juga akan mengakibatkan gangguan transportasi kalsium pada kardiomiosit dan merusak mekanisme eksitasikontraksi sehingga memengaruhi fungsi diastol dan sistol jantung. ${ }^{6,8,9}$

Pemeriksaan fungsi jantung dengan ekokardiografi dapat mendeteksi gangguan fungsi ventrikel secara signifikan sebelum munculnya gejala. Ekokardiografi bersifat tidak invasif, tersedia luas, dan relatif terjangkau. ${ }^{10,11}$

Hubungan kadar kalsium dengan fungsi jantung pertamakali digambarkan oleh Rose tahun $1943 . .^{12}$ Sejak itu, muncul beberapa laporan kasus dan serial kasus tentang gangguan fungsi jantung pada kondisi kadar kalsium yang rendah, tetapi belum ada yang meneliti korelasinya pada penyandang TM. ${ }^{13,14}$ Suatu tinjauan sistematik dan metaanalisis tahun 2014 terhadap laporan-laporan kasus disfungsi dan gagal jantung menyatakan mungkin terdapat hubungan kadar ion kalsium dengan fungsi jantung. ${ }^{13}$

Penelitian ini bertujuan untuk menentukan korelasi kadar ion kalsium serum dengan fungsi ventrikel kiri penyandang TM yang telah mengalami hemosiderosis.

\section{Metode}

Penelitian analitik observasional dengan rancangan potong lintang. Pemilihan subjek dilakukan secara berurutan sampai memenuhi jumlah sampel yang telah dihitung. Subjek penelitian adalah penyandang TM yang datang ke poli Thalasemia Rumah Sakit Dr Hasan Sadikin Bandung pada bulan Desember 2014-Januari 2015. Kriteria inklusi adalah usia 7-14 tahun, memiliki catatan medis lengkap, dan kadar feritin serum $>2500 \mu \mathrm{g} / \mathrm{L}$. Kriteria eksklusi adalah sedang mengalami demam dengan suhu aksila $>37,5^{\circ} \mathrm{C}$, malnutrisi berat, menderita penyakit jantung bawaan atau didapat, dan keganasan.

Pemeriksaan kadar ion kalsium serum dilakukan dengan metode ion selective electrode (ISE), sedangkan dimensi dan fungsi jantung diukur dengan ekokardiografi 2-dimensi, $M$-mode, dan Doppler yang dilakukan oleh dokter spesialis kardiologi anak. Pemeriksaan meliputi dimensi ventrikel (IVS: interventricular septal thickness, LVPW: left ventricular posterior wall thickness, LVIDs: left ventricular dimensions in systole, LVIDd: left ventricular dimensions in diastole); fungsi sistol (FS: fractional shortening, EF: ejection fraction); dan fungsi diastol (IVRT: isovolumic relaxation time, E wave: early diastole, A wave: late diastole). ${ }^{15,16}$ Dilakukan pencatatan data lain yang meliputi usia, frekuensi transfusi, kadar feritin serum, jenis, dan penggunaan kelasi besi. Korelasi antara kadar ion kalsium serum dan dimensi serta fungsi jantung menggunakan uji korelasi Pearson bila data distribusi normal. Bila distribusi tidak normal digunakan uji korelasi Spearman, bermakna bila $\mathrm{p}<0,05$.

\section{Hasil}

Subjek penelitian terdiri atas 38 anak laki-laki dan 29 perempuan dengan usia rata-rata 10,25 tahun. Kadar kalsium rerata 4,87 mg/dL (rentang: 4,01-6,34 mg/dL) dengan frekuensi transfusi terbanyak setiap 4 minggu (46) anak. Jenis kelasi besi deferiprone digunakan paling banyak, yaitu pada 52 anak dibanding dengan jenis deferoxamine dan deferasirox, tetapi penggunaan yang tidak teratur pada lebih banyak anak yaitu 46 (Tabel 1).

Hasil pemeriksaan ekokardiografi menunjukkan nilai abnormal pada dimensi ventrikel kiri (interventricular septal thickness/IVSd: 4,18-12,05 mm, left ventricular posterior wall thickness/LVPWd: 4,02-12,05 mm) dan fungsi diastol (isovolumic ventricle relaxation time/IVRT: 37-81 ms) (Tabel 2). 
Uji korelasi Spearman didapatkan korelasi negatif yang signifikan antara kadar ion kalsium serum dengan nilai LVPWd $(r=-0,25 ; p=0,04)$. Uji korelasi Pearson didapatkan hasil kadar ion kalsium serum mempunyai korelasi negatif yang signifikan dengan parameter fungsi sistol yaitu nilai $E F(r=-0,292 ; p=0,017)$ dan FS $(r=-0,252 ; p=0,039)$ tetapi tidak berkorelasi dengan parameter fungsi diastol $(\mathrm{p}>0,05)$ (Tabel 3).

Tabel 1 Karakteristik subjek penelitian

\begin{tabular}{|c|c|c|c|c|}
\hline Karakteristik & $\mathrm{n}$ & Rerata (SB) & Median & Rentang \\
\hline \multicolumn{5}{|l|}{ Jenis kelamin } \\
\hline Laki-laki & 38 & & & \\
\hline Perempuan & 29 & & & \\
\hline Usia (tahun) & & & 10,00 & $7-14$ \\
\hline Kadar feritin serum $(\mu \mathrm{g} / \mathrm{L})$ & & & 4.453 & $2.520-14.941$ \\
\hline \multicolumn{5}{|l|}{ Frekuensi transfusi (minggu) } \\
\hline Tiap 2 & 4 & & & \\
\hline Tiap 3 & 17 & & & \\
\hline Tiap 4 & 46 & & & \\
\hline \multicolumn{5}{|l|}{ Penggunaan kelasi besi } \\
\hline Teratur & 21 & & & \\
\hline Tidak teratur & 46 & & & \\
\hline \multicolumn{5}{|l|}{ Jenis kelasi besi } \\
\hline Deferiprone & 52 & & & \\
\hline Deferasirox & 12 & & & \\
\hline Deferoxamine & 2 & & & \\
\hline Hemoglobin paska transfusi (g/dL) & & $11,725(0.86)$ & & \\
\hline Kadar ion kalsium serum (mg/dL) & & $4,87(0,44)$ & & \\
\hline
\end{tabular}

Tabel 2 Hasil pemeriksaan ekokardiografi

\begin{tabular}{|c|c|c|c|}
\hline Parameter fungsi ventrikel kiri & Rerata (SB) & Median & Rentang \\
\hline FS $(\%)$ & $36,36(4,66)$ & 36 & $28-51$ \\
\hline $\mathrm{EF}(\%)$ & $66,48(5,31)$ & 66 & $59-79$ \\
\hline E wave $(\mathrm{m} / \mathrm{s})$ & $1,132(0,17)$ & & \\
\hline A wave $(\mathrm{m} / \mathrm{s})$ & $0,701(0,17)$ & & \\
\hline $\mathrm{E} / \mathrm{A}$ ratio & $1,66(0,35)$ & & \\
\hline IVRT (ms) & & 55 & $37-81$ \\
\hline DT (ms) & & 22 & 60-191 \\
\hline IVSd (mm) & & 7,11 & $4,18-12,05$ \\
\hline LVIDd (mm) & $38,40(3,95)$ & & \\
\hline LVIDs (mm) & $24,56(1,82)$ & & \\
\hline LVPWd (mm) & & 7,6 & $4,02-12,05$ \\
\hline
\end{tabular}

Tabel 3 Korelasi kadar ion kalsium serum dengan dimensi, fungsi sistol dan fungsi diastol ventrikel kiri

\begin{tabular}{cccccccccc}
\hline & \multicolumn{1}{c}{ Nilai $\mathrm{c}$} \\
\cline { 2 - 10 } & IVS & LVIDd & LVIDs & LVPW & EF & FS & E/A & DT & IVRT \\
\cline { 2 - 11 } Ion kalsium serum & 0,515 & 0,392 & 0,101 & 0,04 & 0,017 & 0,039 & 0,223 & 0,339 & 0,298 \\
\hline
\end{tabular}




\section{Pembahasan}

Hasil penelitian kami menunjukkan korelasi yang bermakna antara ion kalsium serum dan dimensi ventrikel kiri yang berupa penebalan dinding posterior/left ventricular posterior wall thickness (LVWP). Nilai rentang LVWP (4,02-12,05 mm) lebih lebar bila dibanding dengan nilai normal (4,0-7,0 mm). Hasil tersebut menunjukkan subjek penelitian memiliki dinding posterior ventrikel kiri yang abnormal. Penelitian deskriptif retrospektif sebelumnya, subjek penelitian 16 bayi dengan diagnosis gagal jantung karena hipokalsemia, melaporkan hasil pemeriksaan postmortem 1 bayi yang didapatkan pembesaran ruang (dilatasi) dan berat (hipertrofi) ventrikel kiri. ${ }^{17}$

Penelitian kami mendapatkan korelasi bermakna yang bersifat negatif antara kadar ion kalsium serum dengan nilai ejection fraction/EF dan fractional shortening/FS. Hal tersebut berarti semakin rendah nilai kadar ion kalsium serum maka semakin tinggi nilai EF dan FS. Penelitian sebelumnya, berupa metaanalisis tahun 2014, menyatakan mungkin terdapat hubungan antara nilai EF yang menurun dan hipokalsemia (kadar kalsium rerata: 2,6 mg/ $\mathrm{dL}$, rentang: $1,0-4,3 \mathrm{mg} / \mathrm{dL}$ ); sedangkan penelitian deskriptif retrospektif di Inggris melaporkan pasien gagal jantung dengan nilai median FS yang rendah yaitu 10\% mempunyai kadar ion kalsium serum yang rendah (median: 2,84 mg/dL; rentang: 1,64-4,08mg/ dL). ${ }^{13,17}$ Kedua penelitian tersebut mempunyai subjek pasien terdiagnosis aritmia dan gagal jantung yang merupakan gangguan fungsi jantung yang berat, sedangkan subjek pada penelitian kami belum didapatkan gejala. Subjek penelitian sebelumnya bukan penyandang TM dengan hemosiderosis. Anemia kronik pada TM membutuhkan cardiac output (CO) yang tinggi untuk menjaga oxygen delivery yang cukup untuk metabolisme yang optimal. Peningkatan CO akan meningkatkan preload dan penurunan afterload yang akan terlihat sebagai peningkatan nilai EF dan FS. ${ }^{18}$ Peningkatan EF juga dianggap sebagai tahap awal kardiomiopati, yaitu peningkatan $\mathrm{EF}>60 \%$ atau terdapat hipertensi arteri pulmonal ringan (HAP), regurgitasi mitral (MR), atau trikuspid (TR). ${ }^{19}$

Gangguan fungsi diastol pada penyandang TM berbentuk gangguan restriktif, yaitu nilai E/A $>1,5$ dengan nilai $\mathrm{DT}<150 \mathrm{~m} / \mathrm{s}^{20}$ maka subjek penelitian kami terpenuhi pada 21 pasien, walaupun tidak berkorelasi dengan penurunan kadar ion kalsium. Hal tersebut mungkin disebabkan adanya mekanisme kompensasi pada anemia kronik yang mempertahankan fungsi diastol normal. ${ }^{21}$

Kadar ion kalsium subjek penelitian kami 22 pasien yang mengalami hipokalsemia (nilai normal kadar ion kalsium serum 4,7-5,2 mg/dL) dengan nilai rerata $4,87 \mathrm{mg} / \mathrm{dL}$. Nilai tersebut lebih tinggi dibanding penelitian sebelumya di Inggris (median ion kalsium serum: $2,84 \mathrm{mg} / \mathrm{dL}$ ) yang mempunyai subjek penelitian gagal jantung, ${ }^{17}$ sedangkan subjek penelitian kami tidak ada yang terdiagnosis gagal jantung. Kalsium memegang peran penting dalam kontraksi miokardium dengan mengaktifkan miofilamen yang akan berikatan dengan troponin $\mathrm{C}$ dan selanjutnya akan menginduksi interaksi aktin dan miosin yang mengawali kontraksi miokardium. ${ }^{22-24}$ Kadar ion kalsium yang rendah akan menyebabkan berkurangnya $\mathrm{Ca}$ influx ke dalam miosit untuk mengawali suatu proses kontraksi miokardium. Kontraksi yang berkurang menimbulkan respons kompensasi untuk menambah sel miosit sehingga berakibat peningkatan ketebalan dinding untuk menghasilkan kontraksi yang optimal. ${ }^{25}$

Gangguan fungsi sistol dan dimensi ventrikel kiri yang berkorelasi dengan kadar ion kalsium serum selain karena hipokalsemia diduga juga karena peningkatan besi bebas $\left(\mathrm{Fe}^{2+}\right)$ yang terdeposit pada miokardium. Kondisi kelebihan besi atau hemosiderosis (kadar feritin serum $>2.500 \mu / \mathrm{L}$ ) menyebabkan munculnya besi yang tidak terikat transferin atau disebut non tansferrin bound iron (NTBI). Masuknya NTBI menggunakan LTCC yang merupakan saluran utama masuknya kalsium. Hal tersebut akan mengakibatkan mekanisme kompetisi $\mathrm{Fe}^{2+}$ dengan $\mathrm{Ca}^{2+}$ karena keduanya memiliki ukuran dan muatan listrik yang sama. ${ }^{7}$ Kondisi hipokalsemia akan memungkinkan NTBI $\left(\mathrm{Fe}^{2+}\right)$ masuk lebih banyak melewati LTCC sehingga terdeposit lebih banyak pada miokardium. ${ }^{6,7}$ Non tansferrin bound iron bersifat toksik karena dapat memicu pembentukan radikal bebas. ${ }^{4,5}$ Peningkatan $\mathrm{Fe}^{2+}$ dalam LTCC juga mengganggu transportasi kalsium sehingga memperberat gangguan kontraksi miokardium. ${ }^{6,8,9}$

Keterbatasan penelitian kami adalah kondisi anemia yang memengaruhi fungsi jantung tidak dapat disingkirkan sepenuhnya sehingga peneliti melakukan pemeriksaan kadar hemoglobin pasca transfusi dan ekokardiografi 24 jam pasca transfusi. 


\section{Kesimpulan}

Semakin rendah kadar ion kalsium serum maka semakin tinggi nilai LVWPd, ejection fraction, dan fractional shortening. Kadar ion kalsium serum tidak berkorelasi dengan fungsi diastol.

\section{Daftar pustaka}

1. Rund D, Rachmilewitz E. $\beta$-Thalassemia. N Engl J Med 2005;353:1135-46.

2. Sofro AS. Molecular pathology of the B thalassemia in Indonesia. Southest Asian J Trop Maed Pub Hlth 1995;26:5-8.

3. Al-Tuaikh JA. Hemosiderosis and hemochromatosis. Int Med 2010;1:290-2.

4. Jabbar DA, Davison G, Muslin AJ. Getting the iron out: preventing and treating heart failure in transfusiondependent talasemia. Clev Cli J Med 2007;11:807-16.

5. Papanikolaou G, Pantopoulos K. Iron metabolism and toxicity. Toxcol Applied Pharmacol 2005;202:1-13.

6. Prabhu $\mathrm{R}$, Prabhu V, Prabhu RS. Iron overload in $\beta$ Thalassemia- a review. J Biosci Tech 2009;1:20-31.

7. Qudit GY, Sun H, Trivieri MG, Koch SE, Dawood F, Ackerley C, dkk. L-type $\mathrm{Ca}^{2+}$ channels provide a major pathway for iron entry into cardiomyocytes in ironoverload cardiomyopathy. Nat Med 2003;9:1187-94.

8. Chattipakorn N, Kumfu S, Fucharoen S, Chattipakorn S. Calcium channels and iron uptake into the heart. World J Cardiol 2011;3:215-8.

9. Tushima R, Wickenden AD, Bouchard RA, Qudit GY, Liu PP, Backx PH. Modulation of iron uptake in heart by L-type $\mathrm{Ca}^{2+}$ channel modifiers: possible implications inl iron overload. Circ Res 1999;84:1302-9

10. Vogel M, Anderson LJ, Holden S, Deanfield JE, Lennel DJ, Walker JM. Tissue doppler echocardiography in patients with thalassemia detects early myocardial dysfunction related to myocardial iron overload. Eur Heart J 2003;24:113-9.

11. Marci M, Pitrolo L, Lo Pinto C, Sanfilippo N, Malizia R. Detection of early cardiac dysfunction in patients with $\beta$ thalassemia by tissue doppler echocardiography. Echocardiography 2011;28:175-80.

12. Rose E. Hypoparathyroidism. Clinics 1943;1:1179-96.

13. Newman DB, Fidahussein SS, Kashiwagi DT, Kennel KA, Kashani KB, Wang Z, dkk. Reversible cardiac dysfunction associated with hypocalcemia: a systemic review and meta-analysis of individual patient data. Heart Fail Rev 2014;19:199-205.

14. Tsironi M, Korovesis K, Farmakis D, Deftereos S, Aessopos A. Hypocalcemis heart failure in thalssemic patients. Int J of Hematoloy 2006;83:314-7.

15. Lang RM, Bierig M, Devereux RB, Flchskampf FA, Foster E, Pellikka PA, dkk. Recommendation for chamber quantification: a report from the American Society of Echocardiography's Guidelines and Standards Committee and the Chamber Quantification Writing Group, Developed in Conjunction with the European Association of Echocardiography, a Branch of the European Society of Cardiology. Eur J Echocardiography 2006;7:79-108.

16. Kapusta L, Thijssen JM, Cuypers MH, Peer PG, Daniels O. Assesment of myocardial velocities in healthy children using tissue Doppler imaging. Ultrasound in Med \& Biol 2000;26:229-37.

17. Maiya S, Sullivan I, Allgrove, Yates R, Malone M, Brain C, et al. Hypocalcemia and vitamin D deficiency: an important but preventable cause of life threatening infant heart failure. Heart 2008;94:581-4.

18. Pennel JD, Udelson JE, Arai AE, Bozkurt B, Cohen AR, Galanello R, dkk. Cardiovascular function and treatment in $\beta$-talasemia major. A consensus statement from the American Heart Association. Circulation 2013;128:281-308.

19. Taksande A, Prabhu S, Venkatesh S. Cardiovascular aspect of Beta-Thalassemia. Cardiovasc \& Hematol Agents in Med Chem 2012;10:25-30.

20. Ho CY, Solomon SD. A clinician's guide to tissue Doppler imaging. Circulation 2006;113:396-8.

21. Kremastinos D, Tsiapras DP, Tsetsos GA, Rentoukas EI, Vretou HP, Toutouzas PK. Left ventricular diastolic doppler characteristics in $\beta$-thalassemia major. Circulation 1993;88:1127-35.

22. Garcia JM. Cardiac function in heart failure: the role of calcium cycling. Heart Failure 2010;1:15-21.

23. Bers DM. Cardiac excitation-contraction coupling. Nature 2002;415:198-205.

24. Katz AM, Lorell BH. Regulation of contraction and relaxation. Circulation 2000;102:69-74.

25. Bosi G, Gamberini MR, Fortini M, Scarcia S, Bonsate E, Pitscheider W, Vaccari M. Left ventricular remodeling, and systolic and diastolic function in young adults with $\beta$ thalassemia major: a Doppler echocardiograhic assessment and correlation with haematological data. Heart 2003;89:762-6. 